\title{
Cultural Self-Identification within the Millennial Market: A Qualitative Examination
}

\author{
Lori M. Thanos, D.B.A. ${ }^{1} \&$ Sylvia D. Clark, Ph.D. ${ }^{2}$ \\ ${ }^{1}$ St. Joseph's College, Business Administration \& Marketing Dept., USA \\ ${ }^{2}$ St. John's University, Peter J. Tobin College of Business, USA \\ Correspondence: Lori M. Thanos, D.B.A., Assistant Professor of Marketing, St. Joseph's College Business \\ Administration \& Marketing Dept., Brooklyn, New York 11205, Email: lorithanos@yahoo.com
}

Received: June 15, 2018 Accepted: June 29, 2018 Online Published: July 26, 2018

doi:10.5539/res.v10n3p109 URL: https://doi.org/10.5539/res.v10n3p109

\begin{abstract}
The goal of this study was to examine the degree of cultural self-identification among a sample of U.S. Millennials attending a New York City community college. A case study technique using personal interviews was employed, based on input from twelve Millennials in attendance at a large, public community college in New York City. The object was to explore participants' knowledge regarding their cultural affiliations' effects on ethnic food purchases and consumption. Results showed Millennials' cultural self-identification with cultures differing from their original family background, as well as their knowledge of cultural pluralism. Participants tended to select ethnic foods from one culture above all other cultures. Findings from the present study buttress cultural pluralism as a segmentation method and can assist in development of marketing stratagem, while also furnishing an invaluable contribution to current literature.
\end{abstract}

Keywords: Cultural Self-Identification, Cultural Pluralism, Consumer Behavior, Millennials, Market Segmentation, Financial Crisis 2008, Ethnic Foods

\section{Introduction}

One of the most captivating consumer groups in today's marketplace is Millennials (Kruger \& Saayman, 2015). Major industries are looking to this generational cohort as a large part of their market share due to their distinctive characteristics as consumers, their size, and their deliberate transformative ability in many areas of commerce (Valentine \& Powers, 2013). As the largest population since the Baby Boomers, Millennials represent more than $\$ 200$ billion in annual purchasing power and make-up approximately one-fourth of the United States (Kruger \& Saayman, 2015; U.S. Census Bureau, 2015; Valentine \& Powers, 2013). Unique to this generation, Millennials' increased food spending is forecast at $\$ 50$ billion each year to 2020, with especial emphasis on organics (Ascarelli, 2015; Peregrin, 2015). These factors have the attention of food producers and marketers, making the cohort very appealing to pursue.

\section{Literature Review}

\subsection{Millennials}

According to Thanos and Clark (2017), Generation Y (Millennials) have exhibited strong probability of becoming the most forceful American populace since those born between 1946 and 1964 (Baby Boomers). With over \$200 billion in purchasing power annually, and revering self-centric, pleasure-seeking values and status consumption, the Millennial generational cohort are sought after as a very desired market segment, accounting for just under a third of the U.S. population (Debevec, Schewe, Madden, \& Diamond, 2013; Kruger \& Saayman, 2015; Ntanos, A., Skordoulis, \& Ntanos, S., 2014).

Businesses seeking success among Millennials must recognize the qualities that this segment values (Kell, 2015). Chipotle exemplifies such a business; it acknowledges Millennials' appreciation for natural, organic products (Kell, 2015). The company has made bold changes to its menus, adhering to non-GMOs in its ingredients in an effort to attract American Millennials (Kell, 2015). A 2015 Nielsen study of Americans reports 43 percent of Americans care about non-GMOs ("We are what we eat," 2015). Since Chipotle recognizes the importance of reaching and maintaining a millennial customer base, they often forgo short-term profits to accommodate Millennials by using expensive; but healthier ingredients (Kell, 2015). According to Thanos and Clark (2017), Chipotle's desire to reach the millennial customer in new and profitable ways requires addressing the strong need to acknowledge and build upon this culturally-pluralistic market segment. 


\subsection{Millennial Cultural Self-Identification and Cultural Pluralism}

\section{Cultural Self-Identification.}

Millennials pride themselves on being open, accepting, and nurturing of diversity, and particularly, in cultural self-identification often times different from their family bloodline-defined traditional culture (Demangeot \& Sankaran, 2012; Ford et al., 2012; Kipnis et al., 2013). The implications reflect a necessity for marketers to focus on this particular aspect of the millennial character in the design of their advertisements. The notion of cultural self-identification is put forth by many researchers (Demangeot \& Sankaran, 2012; Kipnis et al., 2013; Ladhari et al., 2015). Moreover, it is this cultural self-identification which significantly drives millennial food purchase and consumption habits, particularly with ethnic foods (Demangeot \& Sankaran, 2012). An additional factor fostering the cultural self-identification notion is McClelland's affiliation need for millennial consumers. Yakup and associates (2011) stressed the importance of friends' influence on food purchasing behavior. It is this behavior which encourages Millennials to choose their own cultural identification often based on friends' associations (Yi \& Park, 2015).

Demangeot and Sankaran's (2012) concept of cultural extensionism seems to be most closely associated with Bartikowski and Walsh's (2015) quantitative study of cultural diversity attitudes and identity-related precursors and buying corollaries. Bartikowski and Walsh (2015) investigated the relationship between how consumers' native and global identities connect to a cautious attitude toward buying foreign goods, preferring domestic alternatives. The study utilized a "consumers' universal-diverse orientation (U-D), a three-dimensional conceptualization of attitude toward cultural diversity functions as a mediator variable in these relationships" (p. 526).

The researchers drew upon a tripartite attitude conceptualization toward social identity and cultural diversity theories to examine these correlations. They used an online questionnaire for a cross-national sample of international graduate students and alumni, resulting in 669 participants with an average age of 35, and 53 percent women (cusp of Generation X and Millennials). After participants completed the survey, it was redistributed to peers and relatives through social media and e-mail. Twenty-one countries were used, including Algeria, Argentina, Australia, and the United States. The short version of the U-D scale was used to measure the three dimensions of UDOO. Finally, purchase reluctance for foreign products was measured by relying on five items that captured the concept of rejecting foreign foods in favor of domestic goods (Bartikowski \& Walsh, 2015). The researchers discovered global identity related positively to cultural contact diversity, while national identity correlated negatively. The findings revealed that hesitancy to buy foreign goods, as interceded by the three UDO elements, escalated with national identity but did not decline with global identity.

\section{Cultural pluralism.}

According to Demangeot and Sankaran (2012), cultural pluralism is defined as "the phenomenon describing individuals within a culture exhibiting elements of multiple cultures - as a result of a transition between cultures or close contact with different cultures" on the individual level (p. 762). Lindridge and associates (2014) reinforced the concept of cultural pluralism by emphasizing the need to understand how culturally-rooted and culturally-interpreted self-identification is critical for consumer behavior researchers to comprehend and integrate. There is an absence of meaningful theories about phenomena in culturally-pluralistic research in application to the consumer behavior realm (Demangeot \& Sankaran, 2012; Pantoja et al., 2014). Moreover, scholars acknowledge that research on how consumers' dispositions, identities, and subsequent consumption habits are influenced by the rearrangement of de-territorialized and geospatially-defined cultural flows is negligible (Cleveland et al., 2016).

\subsection{Marketers' Focus Post 2008 Financial Crisis}

The Great Recession "adversely shaped the global and U.S. economies more universally than any economic downturn since the Great Depression" (Brooksbank, Subhan, Garland, \& Rader, 2015; Rollins, Nickell, \& Ennis, 2014, p. 2727; Zhao, Jiang, \& Li, 2015). Duffy, Northey and van Esch (2017) showed how the global financial crisis can contribute to "wicked problems" in the case of industries key to particular countries, using Iceland as an example. Moreover, Brooksbank and associates (2015) referred to the financial crisis (the Great Recession) as "an on-going post financial crisis "hangover"" characterized by unpredictable consumer behavior and global trading market conditions (p. 600). Their longitudinal study included two waves of mail surveys, comparing groups of New Zealand manufacturers. The two surveys, with 427 and 272 participants, respectively, were conducted during recessionary circumstances and in promising economic conditions. The study sought to compare fruitful marketing strategies between the two time-points. Findings suggested that marketers should increase revenue while lowering costs and finding new methods for doing business.

Considering the magnitude and long-lasting nature of the crisis, focus on strategic marketing management is essential to economic recovery and growth (Anghel, Constantinescu, \& Caescu, 2013). Nickell, Rollins, \& Hellman (2013) examined practical marketing activities for surviving the Great Recession and the resulting outcomes on firms' performance (Rollins et al., 2014). In a multi-part study, the researchers interviewed participants from an assortment of industries, discussing 
how the Great Recession had affected their businesses. Findings indicated that current customer relationship investments seemed to strengthen the firm's position in the market. Moreover, firms who were emerging successfully from the crisis had implemented newer marketing tactics, such as crowd-sourcing and social media, to reach their consumers.

\subsection{U.S. Food Market and Ethnic Foods}

The rising, globally-diverse population is prompting many restaurants in the New York City area to target Millennials for their preference in ethnic, organic food choices (Lutz, 2015; Peregrin, 2015; Simpson, 2015). Millennials are the most diverse population and view culture, including country of origin, as a critical component in how they define themselves, particularly in their food purchase and consumption patterns (Franklin, 2014; Ford et al., 2012; U.S. Census Bureau, 2015; van Esch, Northey, Duffy, Heller, \& Striluk, 2018). Franklin (2014) stressed, however, that marketers are remiss and underleverage marketing to this important segment, who greatly value culture in their consumer behavior. Therefore, marketers would be prudent to explore how to most efficiently and effectively capitalize on this uniquely-defined market.

In conducting two quantitative studies, Marinkovic, Senic, and Mimovic (2015) used surveys to isolate key determinants of specific ethnic-themed restaurant choices as well as elements affecting ethnic restaurants' perceived consumer images. Both studies addressed five factors: restaurant interior, exterior, price, food quality, and service quality. While the first study indicated quality and price were the two most important factors, cultural association also played a significant role in restaurant choice. The second study found restaurant interior to be the most substantial factor.

Ntanos, Skordoulis, and Ntanos (2014) focused on the spending habits of Greek Millennials for organic products. The global organic food market expanded over \$5 billion yearly between 2001 and 2014 (Ntanos et al., 2014; Tsyhankova et al., 2014). Moreover, organic products contribute to public health improvement and environmental protection (Ntanos et al., 2014; Tsyhankova et al., 2014). The consumer behavior of Greek Millennials regarding organic product purchase with definable criteria, such as attitudes toward and cost of organic products as well as organic product consumer preferences, contributed to the need for a culturally-pluralistic market strategy.

\section{Method}

A case study method was used to examine the degree of cultural self-identification within a sample of U.S. Millennials attending a New York City community college. The objective was to uncover a connection between Millennials' desire to self-identify culturally and the existence and recognition of culturally-pluralistic purchase behaviors among Millennials. A survey was conducted among twelve Millennials, eight males and four females, spanning ages 18 to 36 . A Northeastern community college enrolling approximately 25,000 business students served as the sampling frame. Student selection was via purposive sampling, with a recruitment letter inviting students to participate read by professors to their various business classes.

Twenty-five- to forty-five-minute face-to-face depth interviews using semi-structured questions were conducted in a single Chipotle location. Verbatim responses and observations were then analyzed (Fielding, J. Fielding, \& Hughes, 2013).

Participant coding was determined by the accumulation of variables, both similar and dissimilar, including cultural identification, participant characteristics, and food consumption behaviors. Motifs and codes were defined with phrases and terms with common themes (Creswell, 2013). The data were manually analyzed by the researcher from transcribed interviews to determine whether one cultural influence showed up as dominant in the Millennials' purchase and consumption food habits.

Motif identification, systematic coding and text evaluation were part of the content analysis, all utilized to address the research questions. Also, the software analysis NVivo was used to this end (Creswell, 2013; Grbich, 2013). The basis of the categories included cultural identity in relation to consumption and purchase habits from different country cultures. "Cultural identity related to purchase and consumption behaviors from cultures or countries different from those of participants was the basis for the categories. Food is the most common consumption category and is often ethnically cued." (Demangeot \& Sankaran, 2012, p. 769)

\section{Results}

The central research question for this qualitative case study encompasses the depth, breadth, and limitations of this investigation. Uncovered patterns and associated motifs, along with summarized results of the study, are provided.

Q1. What marketing rudiments exist for cultural self-identification as perceived by New York City college Millennials in the U.S. food marketplace? 


\section{Study Respondents - Demographic Profile}

The respondents in this study comprise a sample of multi-cultured NYC Millennials, recognized as such by the U.S. Census Bureau (2014b). One-third of the respondents were female, two-thirds were male, four and eight, respectively. All respondents were between 18 and 36 years of age with a community college level of education. Study results reinforced Census Bureau (2014a, 2014b) projections.

\section{Cultural Frequencies}

All participants self-identified as multicultural, with 11 of 12 citing four or more cultural influences on their food consumption and purchase behaviors. Half had been born in NYC; the remainder were born in South America, Africa, and the Caribbean. Six participants had no Italian bloodline, but specified Italian food among their food consumption influences. In general, millennial students eat more different ethnic foods than those reflected in their family bloodlines. Of 64 ethnic food types, only one-quarter were linked to family bloodlines. Mexican was noted as the single most popular ethnic food, with nine mentions, interestingly none by participants of Mexican lineage. Relatedly, Asian food influence was not derived from family bloodlines, but solely from friends, associates, and/or other sources.

\section{Motifs}

Strongly apparent is the difference between ethnic food consumption and the respondents' family background. Expressing individual cultural connections, particularly with non-family bloodlines, was evident in the study's findings. Respondents asserted their desires to try various ethnic foods and even the desire to assimilate into cultures other than those found within their own cultural bloodlines.

\section{Motif 1. Ethnic Self-Identification.}

Cultural identification in several formats appears 43 times after querying NVivo analysis software. Half of the respondents identified with one single culture among the many with which they had come in contact, regardless of their family orientation and bloodlines. Four of the twelve participants indicated self-identification with associations which were not related to family bloodlines. For instance, Student \#10 expressed cultural identification as choosing one's own culture from many possibilities. "I identify with the Italian culture, even though I am an African-American," stated Student \#5 (Thanos \& Clark, 2017, p. 6).

\section{Motif 2. Culturally-pluralistic Recognition.}

Six respondents acknowledged identifying with a single culture from their multicultural background; that is, cultural pluralism. Only one respondent did not have any thoughts about the influence of a single culture from among many on their purchasing behaviors. The remaining five respondents partially understood the idea of cultural pluralism, which they garnered from their social science or marketing classes. Student \#4 expressed that their cultural identification is derived by which group of friends / people they feel most comfortable with and not necessarily where they come from or where they live now.

The presence of a dominant culture from among those found to be multi-cultured was evident, as over half of respondents stated directly their affinity toward a dominant culture in their purchasing behaviors, particularly with ethnic foods. Student \#9 asserted, "I think it's when you choose your culture among multiple cultures and your preference of acquired backgrounds through exposure to many; but you may choose to associate yourself with a particular culture other than your own family bloodlines." "A predominant culture that influences you from the many you come in contact with," said Student \#4. Additionally, Student \#8 expressed with satisfaction, "I identify with the Italian culture, so I believe it would be a dominant choice when I choose which food I'm going to have most times

\section{Motif 3. Desire to Experience Different Cultures apart from own's own cultural bloodlines.}

All 12 respondents self-identified as multicultural, with Italian, Mexican, South American, and Caribbean cultures being among the top cultural influences. Three respondents specified Asia as a cultural influence.

NVivo turned up over 50 repeatedly-used word frequencies, such as "diverse," “unusual," "different," "new experiences," and "ethnic," when respondents were asked about their tendencies and openness to trying new ethnic foods which did not originate with their traditional or family cultural background. They were among the top 50 sentiments expressed with regard to trying various ethnic foods and influences over their food consumption patterns. All respondents stated they wanted to try new foods, especially from different ethnicities beyond their own traditional bloodlines. Words such as "interesting" and "experience" appeared more than 80 times during the research. Student \#9 claimed, "Eating different foods is part of who I am. I enjoy trying new ethnic foods to see if I can connect with that culture." Almost all students emphasized the need in today's generation to be open to trying new things, especially of cultural difference, and allowing themselves to be influenced by these cultures when making food choices, both purchasing and consumption. Student \#10's demeanor indicated he was proud to experience new foods. He stated, 
I feel my friends influence my choices because, like me, they want to be open-minded about other cultures. I would choose Chipotle over other Mexican places, although I do look for affordability and Chipotle is very affordable and convenient. My friends influence me because we all eat at Chipotle. I follow the Chipotle's page and they make posts which make the food look really good. I'm also attracted to Chipotle's promotions.

\section{Discussion}

Findings suggest that marketing elements do exist to support cultural self-identification as a viable way to create a new market segment among Millennials. Cultural self-identification is evident in the motifs, based on the perceptions of the millennial consumers interviewed. Data also show promising routes for marketers to take in creating a new segmentation variable -- culturally-pluralistic Millennials.

Kipnis and associates (2013) found that self-identification in the modern era is the key determinant of an individual's definition of culture, replacing the traditionally-defined perception (Kipnis et al., 2013). The present research supports this view; in addition, the Millennials interviewed underscored the dominant presence of one specific culture as an influence. This influence came from both family bloodlines and non-bloodline associations.

\section{Implications and Limitations}

Cultural self-identification propels ethnic food purchase and consumption habits of Millennials (Demangeot \& Sankaran, 2012). Armed with this knowledge, marketers can capitalize by targeting a freshly-defined segment, specifically cultural as based on the individuals' perception (Kipnis et al., 2013).

The research of this study uncovered practical uses for marketers in expanding their current marketing stratagem with regard to creating a unique and lucrative market segment. Displaying the millennial cohort in various social media communications, positively experiencing their culturally-diverse interactions, would emphasize the notion of cultural self-identification among this cohort. Using ad campaigns which showcase Millennials' openness to self-identifying culturally could stimulate an increase of sales activity from this market.

Also, using various locations, such as health stores and health clubs, would strengthen the reach to the broader millennial population beyond colleges. The literature reveals that Millennials frequent establishments which focus on the healthier options for products and services (Arman, 2014; Simkin \& Dibb, 2013). Moreover, health clubs and the like offer a platform for this generational cohort to engage socially, which Millennials have a strong leaning toward (Credo, Lanier, Matherne, \& Cox, 2016).

"With a rapidly-increasing globalized society and changing views and trends with regard to cultures and cultural affiliations, it is critical that marketers capitalize on trends in a quick and efficient manner if they hope to remain competitive" (Thanos \& Clark, 2017). Given the noteworthy markers of specific consumer individualities, an emphasis on culturally-sensitive marketing is imperative moving forward (Ladhari, 2015).

The sample size and sampling frame choice present two central limitations. New York City is an unusual market; hence, generalization to other cities would be problematic (Beveridge, 2003). Furthermore, the only college studied was a two-year or community college. These types of colleges are more transitional in nature with regard to their student base, more so than other types of colleges, for instance trade schools and four-year universities and colleges (Nienhusser, 2014). Moreover, the broader millennial population, including those in the workforce alone, was not sampled. According to Yin (2012), twelve is an acceptable and adequate sample size for a qualitative research study. However, by its nature, such research results do not allow for generalization.

\section{Conclusions and Recommendations}

Cultural self-identification is the modern perspective of many Millennials; its existence creates an opportunity for marketers to maintain and expand their competitive advantage in less than flourishing economic times (Mitran \& Bebeşelea, 2012; Rollins et al., 2014). Millennials' leaning toward cultural self-identification, along with their tendencies toward cultural pluralism, should stimulate marketers to pay closer attention to how they can segment this market in this new manner. Through reinterpretation of the millennial segment, marketers can gain a foothold into reengineering and more precisely customizing marketing strategy for this lucrative new market.

Furthermore, according to Bartikowski and Walsh (2015), food preferences largely shape attitudes toward cultural identification from social norms as well as from various reference groups, such as family and friends (Cleveland et al., 2015; Cleveland et al., 2016). "The influence of friends on Millennials to culturally self-identify with their friends' culture as a marketing theme or approach could provide businesses with a competitive advantage not yet explored by other ethnic food restaurants, especially ones which serve spicy food" (Thanos \& Clark, 2017, p. 8).

Future research possibilities include examining whether Millennials outside the New York City area, particularly outside of the community college population, have a strong propensity toward cultural self-identification (Arman, 2014; Simkin 
\& Dibb, 2013). Additionally, a comparison of gender attitudes toward acceptance of cultural self-identification could be probed. Finally, determining whether self-identifying culturally is stronger in individualist versus traditionally collectivist societies could be explored (Butculescu, 2014; Burton, Wang, \& Worsley, 2015; Chang, Liz Thach, \& Olsen, 2016; Debevec et al., 2013; Demangeot \& Sankaran, 2012; Franklin, 2014).

\section{References}

Anghel, L., Constantinescu, M., \& Caescu, Ş. (2013). Innovation within the strategic marketing management of industrial SMES as a response to the economic crisis. Transformation in Business \& Economics, 12(1A), 412-428.

Arman, S. Md. (2014). Integrated model of social media and customer relationship management: A literature review. International Journal of Information, Business \& Management, 6(3), 118-131.

Ascarelli, S. (2015, February 2). Who spends more eating out, Millennials or Boomers? Marketwatch.com. Retrieved from http://www.marketwatch.com/story/Millennials-spend-more-money-in-restaurants-than-boomers-do-2015-01-30

Bartikowski, B., \& Walsh, G. (2015). Attitude toward cultural diversity: A test of identity-related antecedents and purchasing consequences. Journal of Business Research, 68(3), 526-533. https://doi.org/10.1016/j.jbusres.2014.09.010

Beveridge, A. (2003, May 14). How different is New York City from the United States?. Gothamgazette.com. Retrieved from http://www.gothamgazette.com/index.php/state/1826-how-different-is-new-york-city-from-the-united-states

Brooksbank, R., Subhan, Z., Garland, R., \& Rader, S. (2015). Strategic marketing in times of recession versus growth: New Zealand manufacturers. Asia Pacific Journal of Marketing \& Logistics, 27(4), 600-627. https://doi.org/10.1108/APJML-10-2014-0155

Burton, M., Wang, W. C., \& Worsley, A. (2015). Demographic and psychographic associations of consumer intentions to purchase healthier food products. Preventive Medicine Reports, 2, 21-26. https://doi.org/10.1016/j.pmedr.2014.11.006

Butculescu, C. D. (2014). The perception of gender identities within cultural pluralism. Journal of Research in Gender Studies, 4(2), 727-730.

Chang, K. J., Liz Thach, M., \& Olsen, J. (2016). Wine and health perceptions: Exploring the impact of gender, age and ethnicity on consumer perceptions of wine and health. Wine Economics and Policy. https://doi.org/10.1016/j.wep.2016.09.001

Cleveland, M., Laroche, M., \& Papadopoulos, N. (2015). You are what you speak? Globalization, multilingualism, consumer dispositions and consumption. Journal of Business Research, 68(3), 542-552. https://doi.org/10.1016/j.jbusres.2014.09.008

Cleveland, M., Rojas-Méndez, J. I., Laroche, M., \& Papadopoulos, N. (2016). Identity, culture, dispositions and behavior: A cross-national examination of globalization and culture change. Journal of Business Research, 69(3), 1090-1102. https://doi.org/10.1016/j.jbusres.2015.08.025

Credo, K. R., Lanier, P. A., Matherne, I. F., \& Cox, S. S. (2016). Narcissism and entitlement in Millennials: The mediating influence of community service self- efficacy on engagement. Personality and Individual Differences, 101, 192-195. https://doi.org/10.1016/j.paid.2016.05.370

Creswell, J. W. (2013). Research design: Qualitative, quantitative, and mixed methods approaches (4th ed.). Thousand Oaks, CA: Sage Publications.

Debevec, K., Schewe, C. D., Madden, T. J., \& Diamond, W. D. (2013). Are today's Millennials splintering into a new generational cohort? Maybe!. Journal of Consumer Behaviour, 12(1), 20-31. https://doi.org/10.1002/cb.1400

Demangeot, C., \& Sankaran, K. (2012). Cultural pluralism: Uncovering consumption patterns in a multicultural environment. Journal of Marketing Management, 28(7/8), 760-783. https://doi.org/10.1080/0267257X.2012.698635

Duffy, S. M., Northey, G., \& van Esch, P. (2017). Iceland: How social mechanisms drove the financial collapse and why it's a wicked problem. Journal of Social Marketing. 7(3), 330-346.

Fielding, J., Fielding, N., \& Hughes, G. (2013). Opening up open-ended survey data using qualitative software. Quality \& Quantity, 47(6), 3261-3276. https://doi.org/10.1007/s11135-012-9716-1

Ford, R. L., Jenkins, J., \& Oliver, S. (2012). A Millennial perspective on diversity \& multiculturalism. American Advertising Federation. Retrieved from http://aaftl.com/wp-content/uploads/2012/04/Millennial-White-Paper.pdf 
Franklin, E. (2014). Multicultural malarkey. Adweek, 55(26), 19.

Grbich, C. (2013). Qualitative data analysis: An introduction (2nd ed.). Thousand Oaks, CA: Sage Publications.

Kell, J. (2015, April 27). Chipotle just went GMO-free - a savvy move to impress Millennials. Fortune.com. Retrieved from http://fortune.com/2015/04/27/gmo-free-chipotle-Millennials/

Kipnis, E., Broderick, A. J., Demangeot, C., Adkins, N. R., Ferguson, N. S., Henderson, G. R., \& ... Zúñiga, M. A. (2013). Branding beyond prejudice: Navigating multicultural marketplaces for consumer well-being. Journal of Business Research, 66(Recent advances in globalization, culture and marketing strategy), 1186-1194. https://doi.org/10.1016/j.jbusres.2012.08.011

Kruger, M., \& Saayman, M. (2015). Consumer preferences of Generation Y. Journal of Vacation Marketing, 21(4), 366-382. https://doi.org/10.1177/1356766715585903

Ladhari, R., Souiden, N., \& Choi, Y. (2015). Culture change and globalization: The unresolved debate between cross-national and cross-cultural classifications. Australasian Marketing Journal (AMJ), 23(3), 235-245. https://doi.org/10.1016/j.ausmj.2015.06.003

Lindridge, A., Vijaygopal, R., \& Dibb, S. (2014). The manifestation of culture in product purchase: A cross-cultural comparison. Journal of Marketing Analytics, 2(4), 250-263. https://doi.org/10.1057/jma.2014.17

Lutz, A. (2015, May 25). 5 ways Millennials' dining habits are different from their parents'. Businessinsider.com. Retrieved from http://www.businessinsider.com/Millennials-dining-habits-are-different-2015-3

Marinkovic, V., Senic, V., \& Mimovic, P. (2015). Factors affecting choice and image of ethnic restaurants in Serbia. British Food Journal, 117(7), 1903-1920. https://doi.org/10.1108/BFJ-09-2014-0313

Mitran, P., \& Bebeşelea, M. (2012). About the crisis marketing and the crisis of marketing. Economics, Management \& Financial Markets, 7(4), 660-665.

Nickell, D., Rollins, M., \& Hellman, K. (2013). How to not only survive but thrive during recession: a multi-wave, discovery-oriented study. Journal of Business \& Industrial Marketing, 28(5), 455-461. https://doi.org/10.1108/08858621311330290

Nienhusser, H. (2014). Role of community colleges in the implementation of postsecondary education enrollment policies for undocumented students. Community College Review, 42(1), 3-22. https://doi.org/10.1177/0091552113509837

Ntanos, A., Skordoulis, M., \& Ntanos, S. (2014). Millennial consumers' perceptions on the organic products. academia.edu. Retrieved from http://www.academia.edu/8124488/Ntanos_A._Skordoulis_M._and_Ntanos_S._2014_._Greek_Millennial_consum ers_perceptions_on_organic_products._In_Proceedings_of_the_9th_eRA_International_Scientific_Conference_eR A-9_._Piraeus_September_2014._Piraeus_T.E.I._of_Piraeus_accepted

Pantoja, A., Perry, W., \& Blourock, B. (2014). Towards the development of theory: Cultural pluralism redefined. Journal of Sociology \& Social Welfare, 4(1). Retrieved from http://scholarworks. wmich.edu/cgi/viewcontent.cgi? article $=1178 \&$ context $=$ jssw

Peregrin, T. (2015). Practice applications: Understanding Millennial grocery shoppers' behavior and the role of the registered dietitian nutritionist. Journal of the Academy of Nutrition and Dietetics, 115(9), 1380-1383. https://doi.org/10.1016/j.jand.2015.03.022

Rollins, M., Nickell, D., \& Ennis, J. (2014). The impact of economic downturns on marketing. Journal of Business Research, 67, 2727-2731. https://doi.org/10.1016/j.jbusres.2013.03.022

Simkin, L., \& Dibb, S. (2013). Social media's impact on market segmentation and CRM. Journal of Strategic Marketing, 21(5), 391-393. https://doi.org/10.1080/0965254X.2013.801598

Simpson, S. (2015). Chipotle Mexican Grill Inc.: Strategy with a higher mission or farmed and dangerous?. Journal of Case Studies, 33(2), 38-59.

Tsyhankova, T., Yatsenko, O., \& Zavadska, Y. (2014). Global transformations of international organic agrifood markets. Management Theory \& Studies for Rural Business \& Infrastructure Development, 36(2/3), 425-434.

Thanos, L. M., \& Clark, S. D. (2017). A qualitative exploration of culturally-pluralistic segmentation among Millennials. International Journal of Marketing Studies, 9(4), 1-14.

U.S. Census Bureau. (2014a). Ancestry. Factfinder.census.gov. Retrieved from http:/factfinder.census.gov/faces/tableservices/jsf/pages/productview.xhtml?pid=ACS_14_5YR_B04007\&prodTy 
pe $=$ table

U.S. Census Bureau. (2015, June 25). Millennials outnumber Baby Boomers and are far more diverse, Census Bureau reports. www.census.gov. Retrieved from https://www.census.gov/newsroom/press-releases/2015/cb15-113.html

U.S. Census Bureau. (2014b). People reporting multiple ancestry. Factfinder.census.gov. Retrieved from http://factfinder.census.gov/faces/tableservices/jsf/pages/productview.xhtml?pid=ACS_14_5YR_B04005\&prodTy pe $=$ table

van Esch, P., Northey, G., Duffy, S., Heller, J., \& Striluk, M. (2018). The moderating influence of country of origin information seeking on homophily and product satisfaction. Journal of Promotion Management. 24(3), $332-348$. https://doi.org/10.1080/10496491.2018.1378300

Valentine, D. B., \& Powers, T. L. (2013). Generation Y values and lifestyle segments. Journal of Consumer Marketing, 30(7), 597-606. https://doi.org/10.1108/JCM-07-2013-0650

Yakup, D., Mucahit, C., \& Reyhan, O. (2011). The impact of cultural factors on the consumer buying behaviors examined through an impirical study. Ijbssnet.com. Retrieved from http://ijbssnet.com/journals/Vol._2_No._5_\%5BSpecial_Issue_-_March_2011\%5D/13.pdf

Yi, Y. J., \& Park, K. H. (2015). Motivational needs on team performance of Korean nursing students. International Nursing Review, 62(1), 47-53. https://doi.org/10.1111/inr.12164

Yin, R. K. (2012). Applications of case study research (3rd ed.). Thousand Oaks, CA: Sage Publications.

Zhao, X., Jiang, X., \& Li, Z. (2015). The impact of the economic crisis on the financial performance of multinational corporations. International Review of Economics and Finance, 37, 55-68. https://doi.org/10.1016/j.iref.2014.11.013

\section{Copyrights}

Copyright for this article is retained by the author(s), with first publication rights granted to the journal.

This is an open-access article distributed under the terms and conditions of the Creative Commons Attribution license (http://creativecommons.org/licenses/by/4.0/). 